\title{
Fuelwood consumption pattern and its impact on forest structure in Kashmir Himalayas
}

\author{
Patrón de consumo de leña y sus impactos en la estructura del bosque en Cachemira, Himalaya
}

\author{
Hamayun Shaheen ${ }^{a *}$, Beenish Azad a, Aroosa Mushtaq a, Raja Waqar Ahmad Khan ${ }^{\text {a }}$ \\ *Corresponding author: ${ }^{\text {a }}$ University of Azad Jammu and Kashmir, Department of Botany, \\ Muzaffarabad, 13100 Pakistan, phone: +92-344-5952552, hamayunmaldial@yahoo.com
}

\begin{abstract}
SUMMARY
Fuel wood is the major source of energy for the rural populations of Kashmir Himalayas. Immense fuel wood extraction from the local forests has resulted in deterioration of forest structure. Although, the fuel wood extraction pattern strongly impacts the structure and species composition of natural forests, detailed investigations remain scarce. The current research was designed to quantify fuel wood consumption levels and analyze the dynamics; emphasizing on variations in fuel wood patterns along an altitudinal gradient during different seasons and information about the preferred fuel wood species in western Himalayan forest stands of Kashmir, Pakistan. Forest stands were surveyed by using systematic quadrate sampling to determine the impact of fuel wood harvesting on natural forest structure. Fuel wood consumption per household was estimated in $16.2 \mathrm{Mg} \mathrm{year}^{-1}$, and $5.9 \mathrm{~kg}$ day ${ }^{-1}$ per capita (ranging from $6.6 \mathrm{~kg}$ in summer to $3.9 \mathrm{~kg}$ in winter). Consumption at the higher and lower altitudinal villages was recorded as 18.3 and $10.7 \mathrm{Mg}$ annually. Average density for the whole forest stands was calculated to be 73.8 trees ha ${ }^{-1}$, whereas deforestation intensity was 52.95 stumps ha $^{-1}$ and seedling density of 12.87 seedlings ha ${ }^{-1}$. Pinus wallichiana, Abies pindrow and Quercus dilatata were highly exploited species which can lead to the loss of biodiversity and disturbance in the local forests. The results imply that increased fuelwood harvest, combined with low tree density, high population growth and severe climatic conditions, is causing intense forest destruction and associated biodiversity loss. Local forest reserves demand immediate attention in order to conserve the depleting forest structure.
\end{abstract}

Key words: deforestation, altitudinal gradient, climatic conditions, phytosociology.

\section{RESUMEN}

La leña es la principal fuente de energía para poblaciones rurales de Cachemira, Himalaya. Una enorme extracción de leña de bosques locales ha producido deterioro de su estructura. Aunque el patrón de extracción de leña impacta fuertemente la estructura y composición de especies de los bosques naturales, las investigaciones detalladas son escasas. La presente investigación pretendió cuantificar el consumo de leña y analizar su dinámica; se enfatizó en variaciones del patrón de leña a lo largo de un gradiente altitudinal, durante diferentes épocas del año y la identificación de especies preferidas para combustible en bosques del Himalaya occidental de Cachemira, Pakistán. Mediante muestreo sistemático se determinaron impactos de la extracción de leña en la estructura del bosque. El consumo de leña por hogar fue 16,2 $\mathrm{Mg}_{\text {año-1 }}$ y $_{5,9} \mathrm{~kg}_{\text {día }}{ }^{-1}$ per capita (desde $6,6 \mathrm{~kg}$ en verano a 3,9 $\mathrm{kg}$ en invierno); en pueblos altitudinalmente superiores e inferiores fue 18,3 y 10,7 Mg anuales, respectivamente. Para el conjunto de bosques, la densidad media fue 73,8 árboles $\mathrm{ha}^{-1}$, la intensidad de deforestación 52,95 tocones ha- ${ }^{-1}$ y la regeneración 12,87 plantas ha ${ }^{-1}$. Pinus wallichiana, Abies pindrow y Quercus dilatata fueron las especies altamente explotadas que pueden conducir a pérdida de biodiversidad y perturbación en bosques locales. Los resultados implican que el aumento de la recolección de leña, combinada con baja densidad de árboles, elevado crecimiento poblacional y condiciones climáticas severas está causando destrucción intensa del bosque y pérdida de biodiversidad asociada. Las reservas forestales locales exigen atención inmediata para conservar la estructura del bosque.

Palabras clave: deforestación, gradiente altitudinal, condiciones climáticas, fitosociología.

\section{INTRODUCTION}

Forest ecosystem is the primary aid to the sustainable livelihood of Himalayan mountain populations which provides valuable livelihood goods and services in regulating, provisioning, supporting and cultural aspects (Bhatt and Sachan 2004). Fuel wood is the most extensively used form of biomass energy for rural Himalayan population for lightening, heating and cooking activities. Energy needs at the household level in the Himalayan Mountain populations have been fulfilled primarily from forests. Demand and supply for the fuel wood is a serious issue at local and national levels. The energy consumption pattern varies according to climatic conditions, geographical features and socio economic status of the area. Himalayan mountain communities face severe shortage of energy resources due to poor socio-economic status (Démurger and Fournier 2011). 
The fuel wood consumption at large scale is related to the severe environmental problems including deforestation, land degradation, loss of biodiversity, climate change and adverse health effects due to the indoor air pollution. Firewood accounts for over $54 \%$ of all global harvests per annum which results in the huge amount of forest loss (Williams and Shackleton 2002). Himalayan forests are among the most diminished forests around the globe. Wood contributes $90 \%$ of the total energy consumption in Himalayan Mountains. Pakistan is a forest-poor country with only 4.72 million hectares $(5.36 \%)$ of its land mass covered with forest. Fuel wood is the main source of energy in $>80 \%$ of Pakistani households (Shaheen et al. 2011a). Satellite imagery analyses have revealed $27 \%\left(821 \times 10^{3} \mathrm{ha}\right)$ loss of forest cover in Jammu and Kashmir (Joshi et al. 2001).

About $93.7 \%$ housing units in the state of Azad Jammu and Kashmir use wood in order to fulfill their cooking and heating demands. The population of this state consumes huge amounts of fuelwood due to high population density, severe climatic conditions and lack of alternate fuel resources including electricity or natural gas. On the other hand, the forest cover is on rapid decline due to immense fuelwood extraction (Shaheen et al. 2011b). It is critical to determine and analyze the impacts of unplanned and unsustainable fuel wood extraction on forest structure, composition and regeneration (Pant 2013). Although, fuelwood extraction pattern strongly impacts the structure and species composition of natural forests, detailed investigations remain scarce. The hypothesis of the study is that rural populations of Kashmir Himalayas are consuming immense amounts of fuel wood extracted directly from the local forest reserves resulting in negative impacts on structure and composition of the forests, especially on preferred fuelwood species. It also includes that fuelwood consumption levels are directly influenced by environmental factors including altitude and climate as well as socioeconomic parameters such as family size and lack of alternate fuel resources.

The current research was designed to respond to the lack of reliable data on fuelwood consumption and its impacts on forest structure as a whole and fuelwood species in particular in Western Himalayan moist temperate and subtropical forest stands of Kashmir. Specific objectives of the study included the estimation of fuelwood consumption levels by the village communities of Kashmir under varying ecological and socio-economic conditions; and to evaluate the influence of altitude, climate, season, and family size on fuelwood consumption. Objectives also included to determine the impacts of fuelwood extraction on forest structure, regeneration and distribution of preferred keystone tree species in the region.

\section{METHODS}

The study area lies at $34^{\circ} 00.5-34^{\circ} 00.6$ North latitude and $73^{\circ} 46.1-73^{\circ} 45.9$ East longitude in District Bagh, Azad Jammu and Kashmir, Pakistan (figure 1). Topographically the Bagh district is a mountainous area, generally sloping from northeast to south-west having an altitudinal range of $1,300 \mathrm{~m}$ in South to $3,300 \mathrm{~m}$ in North. In winter the main Northern part of the district is very cold having temperatures down to $-5^{\circ} \mathrm{C}$, whereas summers moderate with temperature ranges of $25-30{ }^{\circ} \mathrm{C}$. Annual rainfall is about 1,500 mm (Pak-Met 2012). According to the 2013 survey, the total population of the district was 4.34 million with an annual growth rate of $2 \%$. The average household size is 7.4 per family. Ninety four percent population lives in rural areas. The area harbors subtropical and moist temperate forest stands across the vast altitudinal gradient. Most rural population depends on forest, livestock and agriculture for its subsistence (Shaheen et al. 2011a).

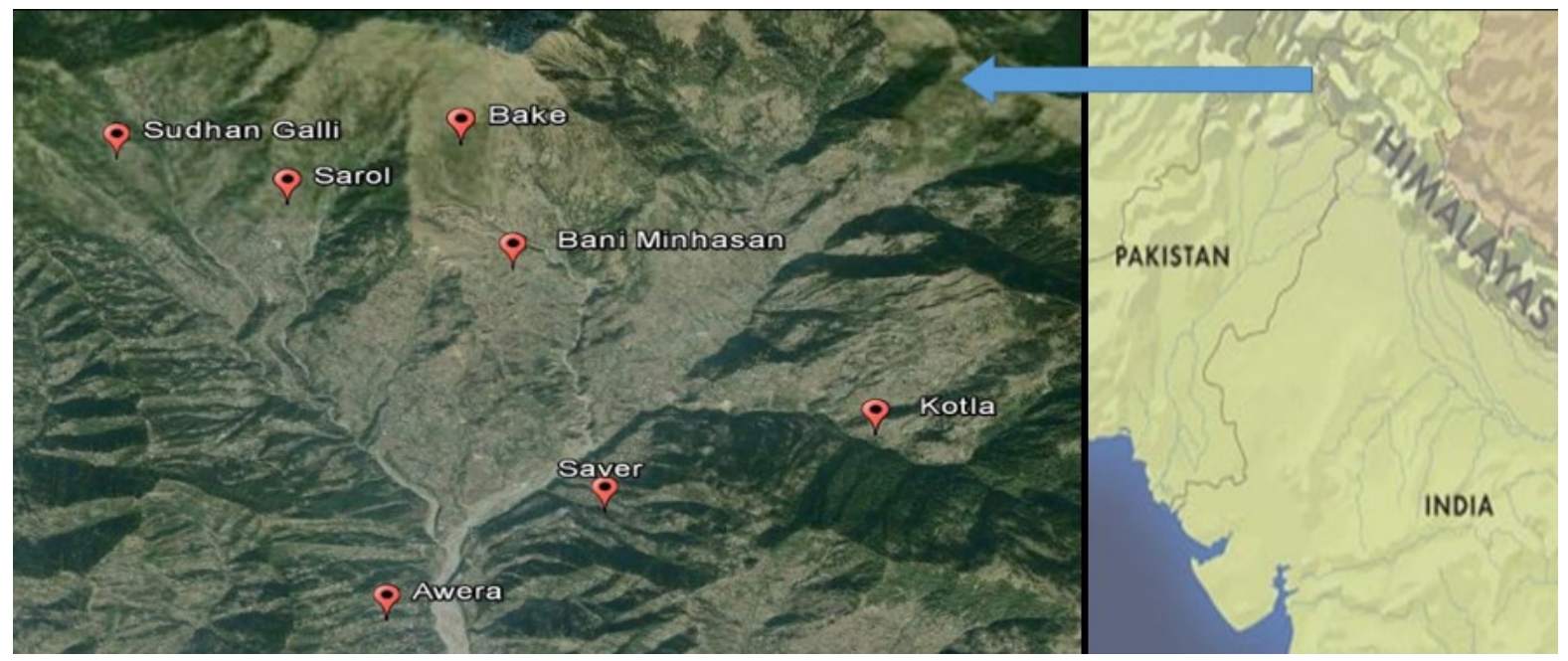

Figure 1. Location of the study area (right) and satellite imagery (left) of sites.

Localización del área de estudio (derecha) e imagen satelital de los sitios (izquierda). 
Seven villages in upper and lower altitudinal ranges of Bagh District were selected to investigate fuelwood consumption pattern and to reveal the impact of altitudinal gradient of fuelwood consumption pattern. The quantity of fuel wood consumed was measured over a period of 24 hours by using a weight survey method (Mijitaba and Jing 2013). Socioeconomic data, including preferred species, family size, occupation, dependence on fuelwood and extraction methods, were acquired by administering 30 questionnaires at each site (total 210). The impacts of fuelwood harvest on forest stands were investigated at the forest reserves using the systematic quadrat sampling method using a size of $20 \times 20 \mathrm{~m}$. In total 10 quadrates were laid at each site to record the structural attributes and phytosociological characters of species were recorded. The characters recorded included density, frequency and cover which were subsequently calculated to compute relative values and importance value index for each species (Ahmed and Shaukat 2012). Deforestation intensity was measured by counting the number of stumps at each site for each species. Similarly regeneration rate was calculated for each species and site by counting the number of seedlings. Altitude, longitude and latitude of each site were recorded using GPS. Results were statistically analyzed by using multivariate ordination programs including principal component analyses (PCA) and cluster analysis to reveal the significant correlations and trends in the data.

\section{RESULTS}

Total average fuelwood consumption for the area was calculated to be $16.2 \mathrm{Mg}$, whereas per capita consumption was found to be $5.9 \mathrm{~kg}$ day $^{-1}$. In summer fuelwood consumption was found to be $3.718 \mathrm{Mg}$, whereas in winter total fuelwood consumption was $12.475 \mathrm{Mg}$. The highest fuelwood consumption was $27.882 \mathrm{Mg}$ recorded at Bake site $(2,630 \mathrm{~m})$, although the lowest fuelwood consumption was $8.913 \mathrm{Mg}$ recorded at Awaira $(1,250 \mathrm{~m})$.

The total fuelwood consumption in the upper Bagh villages was recorded as $18,355 \mathrm{Mg}\left(6.6 \mathrm{~kg}\right.$ day $^{-1}$ per capita $)$, however in lower Bagh villages, the average fuelwood consumption was recorded as $10.78 \mathrm{Mg}$ (3.9 $\mathrm{kg}^{\text {day }}{ }^{-1}$ per capi$t a)$. Eighty five percent population was found to be completely dependent on fuelwood for the energy needs (table 1).

Dominant species from forest stands included Pinus wallichiana with the IVI percentage of $42.0 \%$ followed by Abies pindrow (25.2\%), Quercus dilatata (13.6\%), Pinus roxburghii (9.6\%), Machillus odoratissima (3.0\%), Salix tetrasperma and Aesculus indica (2.2\% each), Olea cuspidata (1.1\%) and Picea smithiana (1.0\%) (table 2).

The average tree density for the whole forest stands was calculated to be 90.99 trees ha $^{-1}$ with the highest value of 125 trees ha $^{-1}$ at Bake, whereas the lowest was 55.8 ha at Saver kalo khan sites. Pinus roxburghii showed the highest density value of 265 trees ha ${ }^{-1}$ followed by Pinus wallichiana (152 trees ha $\left.{ }^{-1}\right)$, Abies pindrow (118 trees ha $\left.{ }^{-1}\right)$, Machillus odoratissima (105 trees ha- $\left.{ }^{-1}\right)$ and Quercus dilatata $\left(97\right.$ trees ha $\left.^{-1}\right)$ and Aesculus indica $\left(27\right.$ trees ha- $\left.{ }^{-1}\right)$.

Deforestation intensity was found to be 72.018 stumps ha $^{-1}$ with the highest value of 110 stumps ha ${ }^{-1}$ at Bake, while the lowest at Awaira (46.66 stumps ha-1). The highest deforestation intensity ( 155 stumps ha $^{-1}$ ) was recorded for $P i$ nus roxburghii followed by Pinus wallichiana (135 stumps ha $\left.^{-1}\right)$, Abies pindrow (87 stumps ha-1 $)$, Quercus dilatata $(68$ stumps ha ${ }^{-1}$ ) and Machillus odoratissima (65 stumps ha ${ }^{-1}$ ).

Average seedling density was determined as 15.3 seedlings ha-1 for the study area. The highest value of seedling density was 18 seedlings ha ${ }^{-1}$ found at Sudhan gali and Kotla, while the lowest value was 10 seedlings ha $^{-1}$ at Bake site. Diospyros lotus had the highest seedling count of 27.5 seedlings ha ${ }^{-1}$ followed by Pinus wallichiana (27.1 seedlings ha- $\left.{ }^{-1}\right)$, Machillus odoratissima (25 seedlings ha $\left.{ }^{-1}\right)$,

Table 1. Annual fuelwood consumption pattern in investigated village populations.

Consumo anual de leña en los poblados investigados.

\begin{tabular}{|c|c|c|c|c|c|c|}
\hline \multirow{2}{*}{ Villages } & \multirow{2}{*}{$\begin{array}{l}\text { Altitude } \\
\text { (m) }\end{array}$} & \multicolumn{3}{|c|}{ Flue wood consumption (Mg) } & \multirow{2}{*}{$\mathrm{kg}$ day $^{-1}$ per capita } & \multirow{2}{*}{ Dependence on fuelwood \% } \\
\hline & & Summer & Winter & Annual & & \\
\hline Saver kalo khan & $1,518-1,642$ & 4.32 & 8.34 & 12.60 & 4.33 & 85 \\
\hline Kotla & $1,943-1,978$ & 3.94 & 9.90 & 13.84 & 4.74 & 95 \\
\hline Sudhan gali & $2,308-2,429$ & 3.60 & 14.64 & 18.24 & 7.13 & 100 \\
\hline Sarool & $2,054-2,233$ & 5.13 & 12.78 & 17.91 & 8.17 & 75 \\
\hline Bani Minhasan & $2,482-2,524$ & 2.25 & 11.65 & 13.90 & 5.44 & 80 \\
\hline Awaira & $1,250-1,353$ & 2.79 & 6.12 & 8.913 & 3.48 & 65 \\
\hline Bake & $2,483-2,630$ & 3.98 & 23.89 & 27.88 & 7.63 & 100 \\
\hline Average & - & 3.71 & 12.47 & 16.19 & 5.90 & 85.7 \\
\hline
\end{tabular}


Salix tetrasperma (22 seedlings ha-1), and Quercus dilatata (17.5 seedlings ha $\left.{ }^{-1}\right)$. Picea smithiana, Pinus roxburghii and Aesculus indica had zero regeneration.

Principal Component Analyses explained that species distribution is strongly influenced by altitude. Species are placed on biplot following the altitudinal stratification as Abies pindrow correlated with Bake and Sudhan gali sites; Pinus wallichiana and Quercus dilatata with Saver and
Bani Minhasan; Picea smithiana and Machillus odoratissi$m a$ with kotla site, whereas Pinus roxburgii with Awaira site in the subtropical region (figure 2). The cluster analysis segregated the sites in three distinct groups. Altitude appears to be the governing factor separating Bake and Sudhan gali sites $(>2,500 \mathrm{~m})$ in $1^{\text {st }}$ cluster, Bani minhasan, Sarool and saver sites $(1,600-2,000 \mathrm{~m})$ in $2^{\text {nd }}$ and Awaira $(1,000 \mathrm{~m})$ in $3^{\text {rd }}$ group due to similar climatic conditions (figure 3 ).

Table 2. Importance values (IVI) and structural attributes of investigated fuelwood species.

Valores de importancia y atributos estructurales de las especies investigadas.

\begin{tabular}{lrrrc}
\hline \multicolumn{1}{c}{ Species } & IVI \% & Stems ha $^{-1}$ & Stumps ha $^{-1}$ & Seedlings ha $^{-1}$ \\
\hline Abies pindrow Royle & 25.2 & 118.0 & 87.0 & 0 \\
Aesculus indica (Wall. ex Camb.) Hook. & 2.2 & 27.5 & 5.0 & 0 \\
Diospyros lotus L & 0.0 & 0 & 15.0 & 27.5 \\
Machillus odoratissima (Wall. ex Nees) Nees & 3.0 & 105.0 & 65.0 & 25.0 \\
Olea cuspidata Wall. ex G.Don & 1.1 & 15.0 & 40.0 & 7.5 \\
Picea smithiana (Wall.) Boiss & 1.0 & 20.0 & 10.0 & 0 \\
Pinus roxburghii Sarg & 9.6 & 265.0 & 155.0 & 0 \\
Pinus wallichiana A.B.Jacks. & 42.0 & 152.1 & 135.0 & 27.1 \\
Pyrus pashia Buch.-Ham. ex D.Don & 0.0 & 0 & 0 & 15.0 \\
Quercus dilatata Royle & 13.6 & 97.5 & 67.5 & 17.5 \\
Salix tetrasperma Roxb. & 2.2 & 12.0 & 3.0 & 22.0 \\
Average & - & 73.8 & 52.9 & 12.9 \\
\hline
\end{tabular}

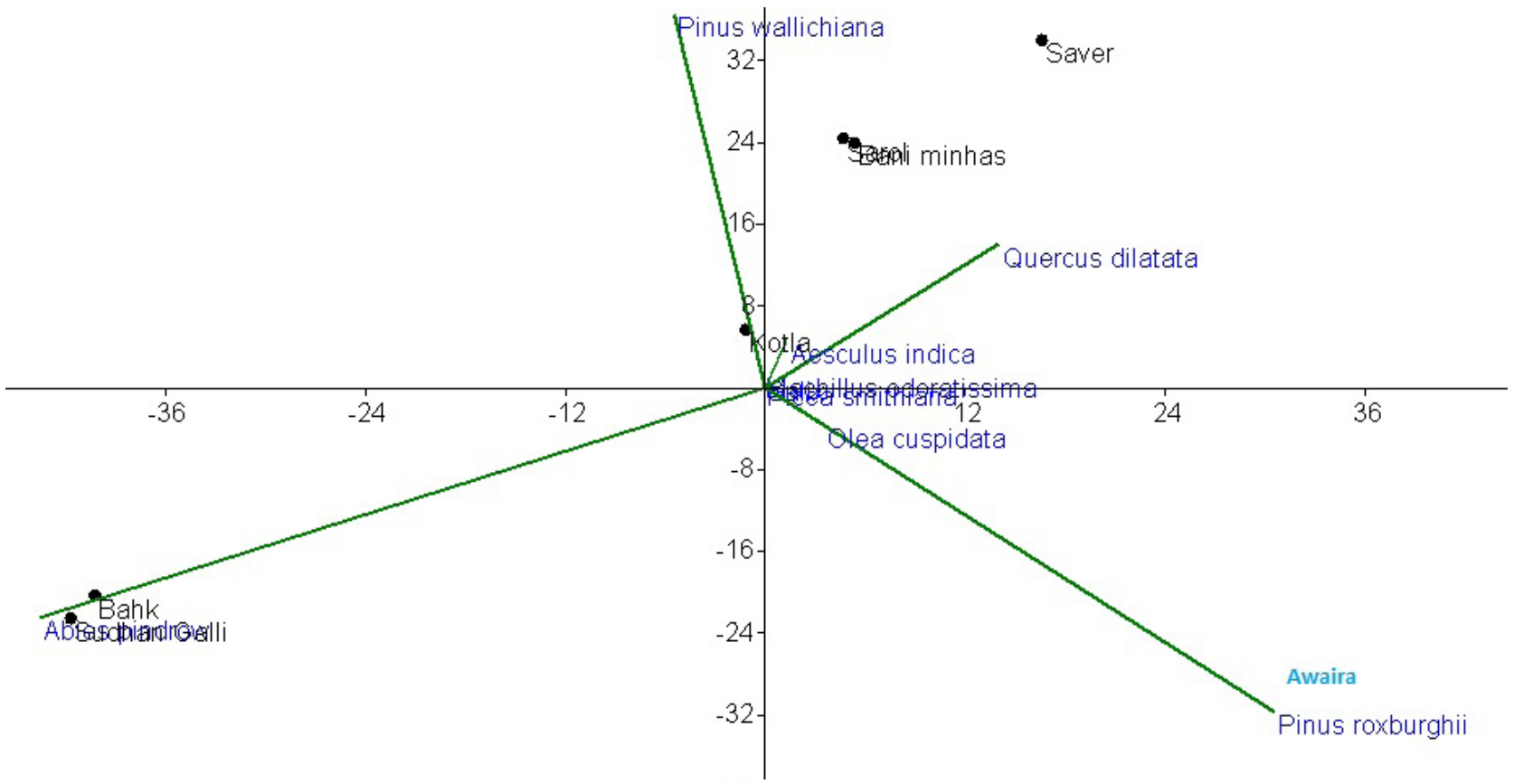

Figure 2. PCA biplot of species and sites dataset.

Análisis de componentes principales para especies y sitios. 


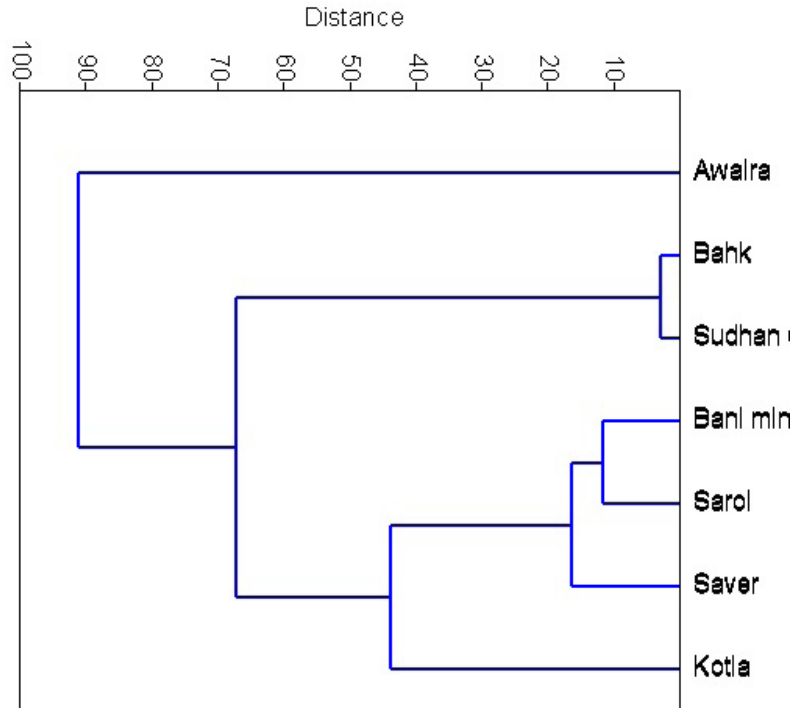

Figure 3. Cluster analyses of sites based on euclidean distance. Análisis de conglomerados de los sitios basado en la distancia euclidiana.

\section{DISCUSSION}

Exploitation of forests for fuel wood extraction has significantly contributed in the destruction of forest resources in the Himalayan region. A current study revealed annual consumption of $16.2 \mathrm{Mg}$ with an average of $5.9 \mathrm{~kg} \mathrm{day}^{-1}$ per capita in different villages of Bagh District. This value is significantly higher than those reported as $3.90 \mathrm{~kg} \mathrm{day}^{-1}$ per capita in Meghalaya, India (Bhatt and Sachan 2004), 1.9-2.2 $\mathrm{kg}$ day $^{-1}$ per capita for Southern India (Hegde 1984), 1.7-2.5 for East Asian countries (Wijesinghe 1984), $1.23 \mathrm{~kg}$ day $^{-1}$ per capita in Nepal (Mahat et al. 1987), and $2.97 \mathrm{~kg}^{-1} \mathrm{day}^{-1}$ per capita for Kashmir (Shaheen et al. 2011b). Average tree density was recorded as 73.8 trees $\mathrm{ha}^{-1}$ in the study area showing declined forest structure. This value is far lesser than those found in the other Himalayan regions: 534-620 trees ha ${ }^{-1}$ in smaller Himalayas (Ahmed et al. 2006); 1,158 trees ha-1 in western Himalayas (Sharma et al. 2008); 530-940 trees ha ${ }^{-1}$ in Kumaun Himalayas (Hussain et al. 2008) and 341-462 trees ha' ${ }^{-1}$ in Nepal broadleaved forests (Subedi and Shakya 1988). The average regeneration of the selected sites was 12.87 seedlings $\mathrm{ha}^{-1}$. Deforestation intensity of the study area was recorded as 52.9 stumps ha- $^{-1}$ (table 2). A strong association was observed among tree felling intensity and population density, fuelwood consumption level and ease of access.

Seasons and climate significantly influence the firewood consumption pattern (Nagothu 2001). During winter increase in consumption is much pronounced (12.4 $\mathrm{Mg}$ ) due to the freezing temperatures, severe climatic conditions and lack of unconventional fuel. Whereas in summer fuelwood consumption dropped to $3.7 \mathrm{Mg}$. Altitude is also a strong determinant of fuelwood consumption level
(Singh et al. 2014). Higher altitudes are characterized by longer winters, low temperatures resulting in high fuelwood consumption. At the high altitude villages $(>2,000$ m) the fuelwood consumption level was found to be 6.6 $\mathrm{kg}$ day $^{-1}$ per capita. Whereas fuelwood consumption in the low altitudinal villages was found considerably lower (3.9 $\mathrm{kg}$ ) compared to high altitude. Local population was found to be heavily dependent ( $85 \%$ ) on fuelwood for their energy needs (table 1). These results support our hypothesis that locals with poor socioeconomic resources, lack of alternate fuels and harsh climatic conditions are forced to rely on forest reserves for the fuelwood extraction.

High fuelwood extraction, along with trampling, land degradation and overgrazing, disturbs the size, structure and composition of the forest (Sharma et al. 2008). The size of gaps produced by natural tree falls also increases, consequently in forest fragmentation, preventing the regeneration of seedlings (Rüger et al. 2007). The preferred fuel wood tree species including Abies pindrow, Quercus dilatata and Pinus wallichiana are under pressure. Tree density of Pinus wallichiana was recorded as 152.1 trees ha- ${ }^{-1}$, far less when compared with 875-929 trees ha ${ }^{-1}$ in Nepal (Pant 2013), 240 trees ha ${ }^{-1}$ in Gangotri India (Dhaulkhandi et al. 2008), and 170 trees ha $^{-1}$ in Uttarkhand India (Rawat and Chandhok 2009). Abies pindrow showed a density of 118 trees $\mathrm{ha}^{-1}$, which is quite low, when compared with reported values of 440-550 trees ha ${ }^{-1}$ in Garhwal Himalaya (Sharma et al. 2008) and 457 trees ha ${ }^{-1}$ in North Western Himalaya India (Singh and Samant 2010). The most alarming threat for the survival of Abies pindrow was its zero regeneration at all the investigated sites.

Quercus dilatata showed a density of 97.5 trees ha ${ }^{-1}$ in the study area. This value is again very low when compared with values 500-1,200 trees ha ${ }^{-1}$ in several Himalayan forests. Regeneration status of Quercus species, 17.5 seedlings $\mathrm{ha}^{-1}$, is also low compared with the other Himalayans regions having values in 270-660 seedlings ha ${ }^{-1}$ range (Nautiyal 2008).

Maximum signs of trampling, grazing and cut stumps were observed on the sites during the survey. Population pressure, synchronized with severe climatic conditions, poor socioeconomic status and ignorance about ecological importance of forest species, has resulted in rapid decline of forest reserves (Putz et al. 2001).

The gap between fuelwood demand and supply can also be reduced by harnessing maximum amount of energy from the fuelwood by adopting efficient burning methodologies. This can be simply achieved by introducing efficient stoves which will ultimately result in decreased pressure on forest reserves (Bhatt and Sachan 2004).

The current work focused on the fuelwood consumption pattern and its impacts on forest structure estimated through robust primary data. Results supported the theoretical hypothesis indicating direct destructive impacts of fuelwood harvesting on forest composition and structural attributes of preferred fuelwood species. These results im- 
ply that increased fuelwood harvest, combined with low tree density, high population growth and severe climatic conditions, is expected to further enhance forest destruction and associated biodiversity loss. Another significant implication of the study is that efforts seeking to restore forest status are not going to have any impact unless the basic deforestation drivers, including high fuelwood extraction, are properly addressed. A comprehensive conservation policy is required to conserve the quickly depleting forest resources of the area.

\section{REFERENCES}

Ahmed M, T Husain, A Sheikh, S Hussain, M Siddiqui. 2006. Phytosociology and structure of Himalayan forests from different climatic zones of Pakistan. Pakistan Journal of Botany 38(2): 361-383.

Ahmed M, S Shaukat. 2012. A Text book of Vegetation Ecology. Near New Urdu Bazar Karachi, Pakistan. Abrar Sons. 430 p.

Bhatt B, M Sachan. 2004. Firewood consumption along an altitudinal gradient in mountain villages of India. Biomass and Bioenergy 27(1): 69-75.

Démurger S, M Fournier. 2011. Poverty and firewood consumption: A case study of rural households in northern China. China economic review 22(4): 512-523.

Dhaulkhandi M, A Dobhal, S Bhatt, M Kumar. 2008. Community structure and regeneration potential of natural forest site in Gangotri, India. Journal of Basic and Applied Sciences 4(1): 49-52.

Hegde M. 1984. Fuel problem in villages: challenges and opportunities. Bulletin of Science 8: 8-13.

Hussain MS, A Sultana, JA Khan, A Khan. 2008. Species composition and community structure of forest stands in Kumaon Himalaya, Uttarakhand, India. Tropical Ecology 49(2): 167.

Joshi P, S Singh, S Agarwal, P Roy. 2001. Forest cover assessment in western Himalayas, Himachal Pradesh using IRS 1 C/1 D WiFS data. Current Science 80(8): 941-947.

Mahat T, D Griffin, K Shepherd. 1987. Human impact on some forests of the middle hills of Nepal Part 4. A detailed study in southeast Sindhu Palchok and northeast Kabhre Palanchok. Mountain Research and Development 7(2): 111-133.

Mijitaba MM, FJ Jing. 2013. Fuelwood consumption in Niger: A review. International Journal of Research Studies in Management 2(2): 67-76.

Nagothu US. 2001. Fuelwood and fodder extraction and deforestation: mainstream views in India discussed on the basis of data from the semi-arid region of Rajasthan. Geoforum 32(3): 319-332.

Nautiyal S. 2008. Structure of central Himalayan forests under different management regimes: an empirical study. Bangalore, India. Centre for Ecological Economics and Natural Resou- rces, Institute for Social and Economic Change. p. 560-572.

Pak-Met. 2012. The Normals of Climatic Data of Azad Jammu \& Kashmir. Islamabad, Pakistan. Pakistan Mateorological Department.

Pant S. 2013. Response of Pinus wallichiana to climate change, a study from Manaslu conservation area, Western Nepal. Master's Thesis in Environmental Science. Kathmandu, Nepal. Central Department of Environmental Science, Tribhuvan University. $61 \mathrm{p}$.

Putz FE, GM Blate, KH Redford, R Fimbel, J Robinson. 2001. Tropical forest management and conservation of biodiversity: an overview. Conservation Biology 15(1): 7-20.

Rawat VS, A Chandhok. 2009. Phytosociological Analysis and Distribution patterns of tree species: A case study from Govind Pashu Vihar, National Park, Uttarakhand. New York Science Journal 2(4): 58-63.

Rüger N, AG Gutiérrez, WD Kissling, JJ Armesto, A Huth. 2007. Ecological impacts of different harvesting scenarios for temperate evergreen rain forest in southern Chile-a simulation experiment. Forest Ecology and Management 252(1): 52-66.

Shaheen H, RA Qureshi, ZK Shinwari. 2011a. Structural diversity, vegetation dynamics and anthropogenic impact on lesser Himalayan sub-tropical forests of Bagh district, Kashmir. Pakistan Journal of Botany 43(4): 1861-1866.

Shaheen H, RA Qureshi, Z Ullah, T Ahmad. 2011b. Anthropogenic pressure on the western Himalayan moist temperate forests of Bagh, Azad Jammu \& Kashmir. Pakistan Journal of Botany 43(1): 695-703.

Sharma R, P Sankhayan, O Hofstad. 2008. Forest biomass density, utilization and production dynamics in a western Himalayan watershed. Journal of Forestry Research 19(3): 171-180.

Singh A, S Samant. 2010. Conservation prioritization of habitats and forest communities in the Lahaul Valley of proposed cold desert biosphere reserve, north western Himalaya, India. Applied Ecology and Environmental Research 8(2): 101-117.

Singh K, A Tewari, N Jeet Ram. 2014. Studies on Vegetational Analysis and Regeneration Status of Pinus roxburghii Roxb. and Quercus leucotrichophora Forests of Nainital Forest Division. Global Journal of Science Frontier Research 14(3).

Subedi M, R Shakya. 1988. Above ground biomass and productivity studies of $Q$. semicarpifolia forest in Nepal. In CHEA and INTACH workshop on Biomass, production and utilization strategies. Nainital India. p. 381-385.

Wijesinghe LCADES. 1984. A sample study of biomass fuel consumption in Sri Lanka households. Biomass 5(4): 261-282.

Williams A, CM Shackleton. 2002. Fuel wood use in South Africa: Where to in the 21 st Century? The Southern African Forestry Journal 196(1): 1-7. 